rubbish) are added to the bonfire- a not uncommon practice-an increased range of carcinogens and other toxic substances is likely to be produced (such as cyanide, ${ }^{2}$ lead, ${ }^{3}$ and, in one particular circumstance, apparently even dioxin, ${ }^{4}$ the Seveso poison). Having contaminated the atmosphere for up to a mile around, some of these toxic substances then settle on the lawns, fruit trees, and vegetable plots of our gardens, and stream through larder vents and open windows to land on food and furniture within the house. Plainly, those guilty of perpetrating this anti-social act are public enemies, although most are probably unwittingly so, never having received any education on this subject.

In addition to any carcinogenic risk, repeated exposure to bonfires could well threaten respiratory health. The irritant gases produced include certain aldehydes and various oxides of nitrogen. Apart from health risks, however, the sickly, evil, and highly characteristic smell of bonfires is alone sufficient to merit their condemnation.

The Clean Air Act of 1956 dealt with bonfires in a patently unsatisfactory manner. (They are permitted unless they cause "a nuisance to the inhabitants of the neighbourhood.") We therefore rely on self-restraint and common sense to see that bonfires are kept to the minimum. The point to be emphasised is that giving up chain-smoking bonfires is infinitely easier than giving up cigarettes; most garden refuse can be composted, and unrottable material can usually be dumped at a nearby householders' tip.

The medical profession is in an ideal position to educate people on the health risks of bonfires, and it is to be hoped that this opportunity is exercised to the maximum. The patient who is cautioned against cigarette smoking can easily also be warned about other sources of smoke such as bonfires. A suitable hand-out could be the Henry Doubleday Research Association's pamphlet "Give up smoking bonfires-make compost and leafmould instead" (obtainable from Lawrence D Hills, Convent Lane, Bocking, Braintree, Essex).

I seem to be conducting something of a lone battle against the bonfire, and I should be extremely grateful if any reader who would support a stricter control of bonfires would send me a postcard incorporating a statement to that effect, indicating, if appropriate, that he is medically qualified. If sufficient support materialises, this would make an influential "petition," and how best to make use of it would be given careful consideration.

SHERRIDAN L STOCK

50 Thong Lane,

Gravesend,

Kent

1 Pybus, F C, Medical Proceedings, 1964, 10, 242

2 Symington, I S, et al, Lancet, 1978, 2,91 . Association,

- Gould, D, General Practitioner, 1978, 23 June, p 44.

SIR,-In the leading article, "Breathing other people's smoke" (12 August, p 453), you say that "Fortunately some authorities... have recognised the rights of the non-smoking majority...." It is, perhaps, worth noting that this enlightenment does not extend to universities. At Kent University, despite requests extending over two years and the official support of the Students' Union, smoking is still allowed in all seminars and many lectures. Furthermore (and given the importance of the common room in student life, this is even worse), at least one master would rather keep rooms locked and empty than allow non-smoking undergraduates to use them as an alternative to the smoke-filled junior common room. Are things this bad at medical universities?

R A McCartney Founder and Chairman of
Society at Kent University

Romford, Essex

SIR,-The leading article (12 August, $p$ 453) on "Breathing other people's smoke" seems both timely and pertinent to my hypothesis (19 August, $p$ 567) that nitrous fumes may be a factor in cot deaths. Both burning gas fires and cigarettes emit nitrous fumes. Cigarette smoke contains between 145 and 655 ppm oxides of nitrogen. ${ }^{1}$

The review of evidence shows that more respiratory illness occurs in children whose parents smoke. A recent study ${ }^{2}$ showed that respiratory infections during the first year of life were closely related to parents' smoking habits in a way that was independent of parental respiratory symptoms, social class, or birth weight. There was also a dose-response relation between parental smoking and infant respiratory infections. An earlier prospective study of hospital admissions during the first year of life found a significant excess $(P<0.001)$ of bronchitis and pneumonia in infants of mothers who smoked.

It is interesting that the research and development division of the British Gas Corporation (19 August, p 567) are pursuing wider and more detailed studies of indoor air quality. Studies of air quality and especially nitrous fume levels in small poorly ventilated rooms heated by different appliances (including cookers) with and without different levels of cigarette contamination would be particularly pertinent. It would be interesting to know also how often cot deaths occur in cold weather, in cramped poorly ventilated accommodation, with gas fire heating or cooking, and where one or both parents smoke.

\section{Department of Respiratory}

Physiology,

City General Hospital,

Stoke-on-Trent Haagen-Smit, A J, Brunelle, M F, and Hara, J,
Archives of Industrial Health, 1959, 20, 53, 399. Colley, J R T, Holland, $W \mathrm{~W}$, and Corkhill, $R$ T,

Lancet, 1974, 2, 1031.
${ }^{3}$ Harlap, S, and Davies, A M, Lancet, 1974, 1, 529.

\section{Self-poisoning by tobacco}

SiR,-The smoking of tobacco produces a multiple, complex (self-) poisoning. Carbon monoxide and vaporised tobacco tar and nicotine are the main poisons in tobacco smoke. These are withdrawn into the mouths of all smokers, and a proportion is inhaled into the lungs of inhalers, who constitute some $90 \%$ of regular cigarette smokers. (I was a cigarette inhaler for 12 years).

Poisoning of the human organism constitutes a disease, and our whole function as a profession is to prevent and cure disease however this has been acquired. How disastrously we have failed to do our job where tobacco-smoke poisoning is concerned is measurable in the billions who now suffer from this disease and who have died from its complications, which are mainly bronchitis with emphysema, coronary heart disease, and cancer, especially of the lung.

What makes our failure inexcusable is that we know how to prevent and cure tobaccosmoke poisoning: by preventing the entry of tobacco into the country. This would be an immense task, but it could, and should, be done. As I pointed out 27 years ago, "A great many people have given up smoking with outstanding benefit to their health, so why not nations?"

Unfortunately the Government, a lay body with a great many preoccupations, was clearly not informed sufficiently about the health damage caused by smoking and has used the powerful craving for tobacco to extract from (sick) smokers enormous sums of money by way of tax. This, of course, is immoral; but we are the real villains, the grossly inefficient watchdogs of the nation's health. We have let down the people grossly. We must demand the quick and total abolition of the death-dealing disease, tobacco smoking.

Up to now we have held the bridge against the smoking of cannabis and opium, but our defences against that other powerful and toxic drug of addiction, tobacco, have been almost hopelessly breached. It is high time we put that right.

LENNOX JOHNSTON

Lymington, Hants

1 Johnston, L, Lancet, 1953, 2, 571.

\section{Health of King Henry VIII}

SIR,-With reference to the preamble of your leading article "Preventing $\mathbf{R} h$ haemolytic disease" (29 July, p 307), we wish to declare an historical interest in the relevant medical theories concerning King Henry VIII.

The King married six times between 1509 and 1547 (from accession to his death). Notwithstanding two male births-namely, Henry Fitzroy, an illegitimate son by Lady Elizabeth Blount, and Edward VI, by Jane Seymourwho both died before reaching adulthood, the total known births surviving to maturity numbered just two. These were both females and firstborn. ${ }^{1}$ The total number of surviving births to the King-four-over a period of 38 years is far below average in contemporary, or near contemporary, society.

Although there is strong evidence of an $R h$ incompatibility with the first wife, referred to in your preamble, ${ }^{2}$ and the additional possibility of syphilis, since discounted with some authority, ${ }^{3}$ neither of these factors may be relevant to a primary question which represents the main purpose of our letter. We wish to inquire, from a genetic point of view, whether a detailed comparable medical history is known of a man whose relevant offspring (in this case, the appalling number of some 12 known fetuses, including miscarriages possibly due to a bad obstetric history) were either stillborn or died neonatally or failed to reach maturity in the male line over a long period and by several (at least four) wives? Without wishing to labour the obvious, Elton's comment, " "the persistent and fatal sickliness of the Tudor stock," just will not do.

We are interested in the possibility of a congenital complication due to some genetic impediment which resulted in the nonsurvival of the issue of Henry VIII over the period of all his marriages, and his later failure to sire children with two other wives.

New information has recently emerged 